\title{
The effect of corporate governance on financial performance of rural banks in Ghana
}

\author{
Alhassan Musah ${ }^{1}$, Mavis Yaa Adutwumwaa ${ }^{2}$ \\ Department of Accounting and Finance, School of Business, Dominion University College, Accra, \\ Ghana ${ }^{1}$ \\ Department of Accounting and Finance, School of Business, Kwame Nkrumah University of Science \\ and Technology, Kumasi, Ghana ${ }^{2}$ \\ a.musah@duc.edu.gh $h^{1}$ obaayaa44@yahoo.com ${ }^{2}$
}

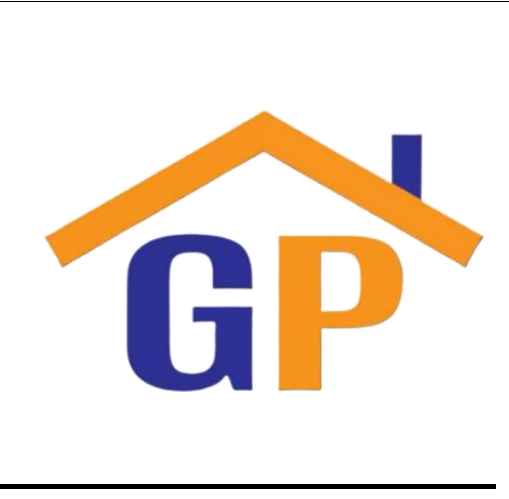

Article History

Received on 17 December 2020

$1^{\text {st }}$ Revision on 4 January 2021

$2^{\text {nd }}$ Revision on 14 January 2021

Accepted on 20 January 2021

\begin{abstract}
Purpose: The study examined the influence of various corporate governance structures such as board size, board independence, board gender diversity and CEO duality on the financial performance of rural banks in Ghana.

Research methodology: The study collected secondary data from the annual report of 30 rural banks for a 10 -year period spanning 2010 to 2019. The data was coded into excel and exported into STATA where descriptive statistics, correlation analysis and regression analysis were adopted to answer the research questions.
\end{abstract}

Results: The result shows that there was a positive but statistically insignificant association between CEO duality and ROA and ROE. The study further reveals a positive association between board size and ROA and ROE even though that of ROA was statistically insignificant. Also, board independence was found to be a significant determinant of rural bank financial performance In addition to the above, the study reported a negative association between gender diversity on the boards of the rural bank and ROA and ROE and both associations were statistically significant.

Limitations: As a result of the lack of publicly available data on rural banks in Ghana, the study relied on only 30 out of the over 100 rural banks currently operating across the country.

Contribution: The result of the study will help the Bank of Ghana and the ARB Apex Bank in their formulation of an appropriate corporate governance framework for rural banks in Ghana and enlighten managers of rural banks on corporate governance structures that enhance their financial performance in Ghana.

Keywords: Corporate governance, Rural banks, Return on Assets, Return on Equity, Ghana

How to cite: Musah, A., \& Adutwumwaa, M. Y. (2021). The effect of corporate governance on financial performance of rural banks in Ghana. International Journal of Financial, Accounting, and Management, 2(4), 305-319.

JEL Classification: C14, D24, G21, G32, G34

\section{Introduction}

Every nation's socio-economic development is globally dependent on how strong its financial institutions. A strong financial institution forms a good basis for the growth of the country's economy. Financial institutions have been identified as a major role player in terms of the development and growth of every economy globally (Sarkar and Sarkar, 2018; Appiah et al., 2015; Anbar and Alper, 2011). Profitability and performance of the bank are determined by their ability to effectively and efficiently carry out their strategic goals (Oteng-Abayie et al, 2018; Mills and Amowine, 2013). 
Banks characterized by effectiveness, strong functioning systems and efficiency are peremptorily having better grounds to resist negative shocks within the economy which might obstruct their performance. However, rural banks and community banks, unlike the commercial bank's performance are not stable due to their low earnings capacity (Oteng-Abayie et al, 2018).

A review of RCB's performance from Bank of Ghana (2001) report outlined some economic shocks as a result of fraud and embezzlement of funds, incompetence on the part of management, ineffective directors on the board, negligence, improper procedures adopted during accounting processes, deviations from regulations relating to compliance for granting loans or credits, high operational cost due to losses, corruption and poor procedural steps in loans recovery, poor mobilization of deposits, employing unqualified staffs, zero filing of returns, acquiring high zero-performing assets and zero returns from high loans disbursed as reasons for low performance of rural banks. The abovementioned indicators outlined by Bank of Ghana (BoG) led to the shutdowns of 23 rural and community banks in 2007 as at June (Aboagye and Otieku, 2010) and 70 Community Banks (MFI) in 2016. According to Adu-Amoah et al. (2008), banks performance should correlate significantly with local economic data. However, banks performance can be associated with the falling of quality loan portfolios (Musah et al. 2019). According to Anbar and Alpher (2011), the performance of banks is as a result of seasonal flows of deposits and loans. Notwithstanding, contemporary studies from the banking industry depicts environmental variable as an important ingredient in banking activities.

Despite the findings and contributions being made by rural banks towards developing the country as a whole, it is still characterized by low deposit. The multiplicity of possible factors that can influence bank performance account for the growing number of studies to determine which factors have the most significant impact (Musah et al. 2019). Although there are a number of studies on rural bank performance and profitability, empirical evidence on the subject of corporate governance and performance in the rural banking industry in developing countries more precisely in the case of Ghana is rare.

Research has shown that good corporate governance contributes significantly towards banks economic efficiency and growth as well as enhance the confidence of investors (Antwi and Binfor, 2013; Adusei, 2011; Aboagye and Otieku, 2010; OECD, 2004). Other strands of literature argue that good corporate governance enhances firm access to external financing, reduces their cost of capital and improves their operating performance (Abor and Biepke, 2007; Abor and Adjasi, 2007; Claessens and Fan, 2003). Musah et al. et al (2019) in their study argued that investors have a preference for well-governed firms by paying more premiums for companies with good corporate governance than those without. These results and evidence suggest that good corporate governance enhance the financial performance of firms which include banks.

A study by Adnan et al. (2011) argue that strong corporate governance for commercial banks is far more important than other corporate entities. In line with the above arguments, several studies have examined the effect of various corporate governance structures on the financial performance of banks (Musah et al. 2019; Bopkin and Arko, 2009; Adusei, 2011; Aboagye and Otieku, 2010). What is debatable in literature is what corporate governance structures is associated with improved financial performance. According to Oteng-Abayie, (2017) and Oteng-Abayie et. al, (2018); over the past three decades since rural banking was introduced in Ghana, it has been characterized by threats of liquidation resulting in the collapse of twenty-three rural banks. Findings from their studies suggest a strong link between corporate governance and performance of rural banks. Literature on corporate governance studies and firm performance in Ghana have focused mostly on listed firms and banks (Bopkin, 2011; Bopkin and Arko, 2009; Isshaq et al. 2009; Abor and Biepke, 2007) and some on commercial banks (Musah et al, 2019; Adusei, 2011; Kyereboah-Coleman and Biepke, 2006). Very limited studies have examined corporate governance of rural banks in Ghana even though these studies did not link it to their financial performance (Adu-Amoah et al. 2008; Oteng-Abayie, 2017). The interest of corporate governance studies and firm performance and efficiency in their financial sector have targeted large commercial banks leaving rural banks who play critical role in the economy out. Hence, this current work seeks to fill the gap by presenting empirical findings that seek to link corporate governance and financial performance of rural banks in Ghana. 
The study contributes to literature and practice in a number of ways. First of all, the study is among a few studies on corporate governance and financial performance of rural banks in Ghana hence it contributes towards the literature on rural bank governance. Second, the study extends corporate governance variable of rural banks to include gender diversity of the board and CEO duality which have received little attention in corporate governance literature in Ghana. The result of the study will help the Bank of Ghana and the ARB Apex Bank on their formulation of appropriate corporate governance framework for rural banks in Ghana. The result will help enlighten managers of rural banks on corporate governance structures that enhance their financial performance in Ghana.

The concept of rural banking in Ghana is traced back to 1972 when the concept was believed to have been borrowed from the Philippines to help provide funding to rural economic activities that cannot secure financial support from the traditional financial sector (Oteng-Abayiie et al. 2018). Research shows that this was after a nationwide consultative study commissioned by the Bank of Ghana recommended the setting up of rural banks (Owusu-Antwi et al. 2015). The objective was to fill the gap in financing for rural economic activities to help propel growth in rural Ghana. The main functions of rural banks were to mobilize savings in their catchment areas and also to provide credit to support micro-activities in these areas. The banks were also mandated to help inculcate the culture of banking in the rural people to help drive economic activities. According to Owusu-Antwi et al. (2015) rural banks in Ghana are unique in terms of ownership and management structure as well as operations. Majority of rural banks are owned by community members through acquisition of shares.

The first rural bank was set up in the Central region in 1976 in a town called Nyarkrom. Between 1980 and 1984, there were about 106 rural banks as many communities wanted to have their own rural bank. In 1981, the managers and directors of rural bank formed the ARB Apex Bank to promote collaboration and sharing of information to improve the financial performance of rural banks in Ghana (Owusu-Antwi et al. 2015). Over 140 rural banks are operating in all parts of the country with a larger concentration of rural banks in Ashanti, Eastern, Brong Ahafo and Central Regions. The Bank of Ghana is currently the regulator of Rural banks even though at some point in time the ARB Apex Bank played that role. This resulted in the enactment of the non-bank financial institution Act, 2008, Act 770 to regulate rural banks and other non-bank financial institutions and recently the enactment of banking and specialized deposit-taking institutions Act 2016, Act 930. The Bank of Ghana has delegated a large part of its supervisory powers to the ARB Apex Bank in the regulations of rural banks in Ghana. The financial sector clean-up exercise over the last few years is yet to affect rural banks even though the minimum capital requirement for rural banks have been increased. At the moment, no rural bank has been collapsed or licensed withdrawn as is the case for commercial banks, microfinance institutions and fund management companies. Perhaps, the Bank of Ghana and government understand the important role rural banks play in the local communities hence their decision to suspend the clean-up exercise in that sector for now.

\section{Literature review and hypothesis development}

\subsection{Board size}

The number of directors on the board of an organization is an important measure of good corporate governance and represent the size of the board. While some researchers argue that small board size limits social loafing and free riding, others also believe that large board size affects effective communication and coordination among others (Golden and Zajac, 2001; Musah et al. 2019). As a result, the right number of members to constitute a board has drawn the attention of researchers. While Monks and Minow (1995) suggested thirteen members, whereas Gersick (1988) has also proposed 5 to 6 members.

In terms of empirical research, Adams and Mehran $(2008 ; 2005)$ in their studies found that board size positively influences the financial performance of banks in the United States of America based on a sample of 35 of the biggest banks in the US. Their study further revealed banks with large board sizes were positively associated with performance measured using Tobin's Q. Andres and Valledo (2008) 
in a related study based on a sample of large commercial banks in some European countries namely, France, United Kingdom, Spain and Italy as well as the United States of America and Canada from the other parts of the world and found that a positive relationship between board size and bank financial performance. Their study further found that having many directors on the board of a bank is positively associated with monitoring and advisory functions, improved governance, as well as increase firm returns. The study, however, placed the maximum number of board members to 19 .

On the other hand, some studies found contrary evidence to those analyzed above by indicating that large board size reduces firm performance. For instance, Staikorous et al (2007) in their study based on 58 large banks from Europe between 2002 to 2004 found a negative association between board size and bank performance. Also, Labelle and Trabelsi (2010) reported that adding more board members to the board is associated with decreasing financial performance of banks measured using Tobin's Q. Some studies contrary to the two strands of literature above found no significant association between bank board size and its financial performance (Ramano et al. 2012). The study used a sample of 25 commercial banks sampled from Italy for the period 2006 to 2010 and reported a negative relationship between the size of bank board and ROA and ROE even though the relationship was insignificant statistically. Theoretically, there is a contrasting argument on the impact of board size on the financial performance of financial institutions. This study argues that large board size increase board expertise, and their monitoring capacity hence the study hypothesizes that;

H1: There is a positive association between board size of rural banks and their financial performance

\subsection{Board composition}

Board composition in corporate governance literature examines the ratio of executive and nonexecutive directors on the board of an organization. Andres and Vallelado (2008) in their study argued that organization who have more representation of outside directors on their board have significant benefits to the company since it helps to check conflict of interest and also and helps to improve the board monitoring of management. Some studies, however, argue that even though non-executive directors on the board enriches the board of a company, they caution that too many non-executive directors will increase information asymmetry between the board and management which will affect the quality of the board monitoring role (Musah et al. 2019; Abad et al. 2017). Romano and Guerrini (2012) in their study found evidence of reduced fraud in financial reporting with the presence of more non-executive directors. A review of corporate governance literature shows that previous studies on the above variable and performance have produced mixed results. In the first place, some studies have reported no significant association between board independence and financial performance of firms. For instance, Love and Rachinsky (2007) in their study using a sample of 50 commercial banks in Russia and Ukraine found no significant association between non-executive directors and bank financial performance. This was consistent with the findings of, Kyereboah-Coleman (2007) and Kyereboah-Coleman and Biekpe (2006). Some empirical studies on the other hand found evidence of a significant relationship between board composition and financial performance of financial institutions. For example, Busta (2007) in a study based on a sample of 69 listed banks across some major European countries found that board independence improves banks performance in countries such as Germany, France while they found a negative and significant association in the UK. Staikouras et al. (2007) in their study also reported a positive relationship between independent directors and the financial performance of banks in Europe. The authors further argue that nonexecutive directors are more independent and objective on their views on corporate issues which helps to improve the board monitoring role efficiently. In line with the above evidence and arguments, the study hypothesizes that:

\section{H2: The proportion of non-executive directors is positively related to rural bank performance.}

\subsection{Duality of $C E O$}

CEO duality as a concept in corporate governance literature can be defined as the condition where one individual holds the position of both the board chairperson and the Chief Executive Officer or its equivalent in the bank. Several studies have included this variable is corporate governance literature 
and which have produced mixed results. For instance, Belkhir (2009) in a study using 174 banks over a 7-year period found that CEO duality was positive and statistically significant with Tobins Q which was used to measure bank performance. Other studies also found contrary evidence where banks with CEO duality performed lower than their counterparts with separation of CEO and board chairperson (Pi and Timme, 1993). Similarly, Mishra and Nelsen (2000) reported a negative association between CEO duality and bank performance using ROA and ROE. Some other studies found no evidence of significant association between CEO duality and performance (Boussaada and Karmani, 2015). The agency theory advocates for the separation of the CEO role and the chairperson of the board to guarantee the independence of the role and their ability to monitor the behavior of management. Based on the above argument and in line with modern principles of good corporate governance the study hypothesizes that;

H3: There is a negative association between CEO duality and firm performance of rural banks in Ghana

\subsection{Gender diversity}

Diversity on the board is one principle of good corporate governance that has been encouraged in several corporate governance studies (Musah et al. 2019; Bopkin, 2011). One of such board diversity that has attracted much attention in literature especially in developed countries is the proportion of women on the board (Musah et al. 2019). Empirical evidence of the relationship between gender diversity and financial performance of firms have produced mixed results. For instance, Heinfeldt (2005) found a positive association between women on board and the market value of firms. Musah et al. (2019) in their study on commercial banks in Ghana found no significant association between gender diversity and bank performance in Ghana. De Cabo et al. (2012) in a similar study in Europe also found no significant association between the two variables based on a sample of 612 banks in Europe. On the other hand, Romano et al. (2012) found evidence of a positive association between women representation on the board and the financial performance of banks. Selvam et al (2006) in a similar study in India also reported a positive association between gender diversity and bank financial performance. Given the results of the empirical evidence adduced and in line with the agency theory, the study hypothesizes that:

\section{H4: Banks performance is positively related to the proportion of female Directors on the rural board of directors.}

\section{Research methodology}

This study relied on quantitative research design for a number of reasons. First, the study seeks to present an analysis of the relationship between corporate governance variables and financial performance of rural banks in Ghana which can best be achieved using quantitative approach. Second, the study used secondary data extracted from the annual report of rural banks in Ghana which are numerical in nature and hence the use of quantitative approach. Also, in line with the positivist view, quantitative approach best suits the study. The population of the study include all rural banks in Ghana registered under ARB Apex Bank in Ghana across the country. The population of Rural banks in Ghana according to the ARB Apex bank website is 140. A total of 30 rural banks were sampled for this study. The choice of the 30 rural banks was based on the availability of published financial statements of these banks on their official website. It was revealed during the data collection process that the majority of the rural banks did not publish their financial statement on their website whiles some did not even have an official website. To improve the sample observation needed to achieve the objectives of the study, the study adopted the panel to ensure that more sample observation will be collected to achieve the objective of the study. The study period in line with the panel was from 2010 to 2018 as 2019 financial statements were yet to be published. 
The study adapted the panel regression model to examine the association between corporate governance practice and financial performance of rural banks in Ghana. The empirical model adopted by the study is presented below:

$$
\begin{aligned}
\text { ROA }_{i t}=\beta_{0}+ & \beta_{1} \text { CEODuality }_{i t}+\beta_{2} \text { BDSize }_{i t}+\beta_{3} \text { BDInd }_{i t}+\beta_{4} \text { GederDiversity }_{i t} \\
& +\beta_{5} \text { Firm Size }_{i t}+\varepsilon_{i t} \\
\text { ROE }_{i t}=\beta_{0}+ & \beta_{1} \text { CEODuality }_{i t}+\beta_{2} \text { BDSize }_{i t}+\beta_{3} \text { BDInd }_{i t}+\beta_{4} \text { GederDiversity }_{i t} \\
& +\beta_{5} \text { Firm Size }_{i t}+\varepsilon_{i t}
\end{aligned}
$$

Where

\begin{tabular}{|l|l|l|}
\hline Variable & Meaning & Measurement \\
\hline ROA & Return on Assets & $\begin{array}{l}\text { The ratio of net profit after tax } \\
\text { over Total Assets }\end{array}$ \\
\hline ROE & Return on Equity & $\begin{array}{l}\text { The ratio of profit after tax } \\
\text { over total equity }\end{array}$ \\
\hline BDSize & CEO duality & $\begin{array}{l}\text { Dummy, 1 if the rural bank } \\
\text { CEO is the board chairperson, } \\
\text { 0 Otherwise }\end{array}$ \\
\hline BDInd & Board Size & $\begin{array}{l}\text { The number of members on the } \\
\text { board of the rural bank }\end{array}$ \\
\hline GenderDiversity & Board Independence & $\begin{array}{l}\text { Non-executive directors divided } \\
\text { by total board size }\end{array}$ \\
\hline FirmSize & $\begin{array}{l}\text { Gender representation on the } \\
\text { board }\end{array}$ & $\begin{array}{l}\text { Number of women on the board } \\
\text { divided by total board size }\end{array}$ \\
\hline
\end{tabular}

\subsection{Dependent variables}

The study used two dependent variables to measure rural bank financial performance. Return on Assets and Return on Equity are the two dependent variables representing rural bank financial performance. Return on assets in one of the most used variables in literature to measure firm performance. For instance, Musah (2017) in the study the effect of capital structure on performance of commercial banks in Ghana, used Return on Assets as the dependent variable. Similarly, Musah et al. $\underline{(2019)}$ in their study of the effect of corporate governance and gender diversity of bank performance in Ghana also used Return on Assets as a measure of bank performance. The use of return on assets as a measure of performance is justified on the basis that it measures the bank's ability to use its assets to generate returns in the form of profit. These studies and many other studies also include return on equity as a measure of bank performance. In effect, the study is using the return on equity because it examines how much profit has the bank generated on the equity investment of the bank.

\subsection{Independent variables}

The main independent variables for the study are the corporate governance variables which include CEO duality, Board size, Board independence, Board gender diversity. The study includes firm size as a control variable as many studies have found evidence of a positive relationship between the size of a bank and financial performance. The corporate governance variables in the study examined various governance structures that are critical for the efficient running of any organization. The extent to which these variables affect firm or bank performance vary from one study to the other. The study seeks to examine these variables in the context of rural banks in Ghana. CEO duality is used as one of the main corporate governance variables that are believed to influence the financial performance of firms. Research shows that board chairperson who acts as CEO have adequate information to help steer the strategic direction of the company (Amoateng et al. 2017). Another strand of literature argues that board chairperson acting as the CEO compromises the neutrality and independence of the board hence does not make it effective in monitoring management (Musah et al. 2019; Owusu-Antwi et al. 2014; Oteng-Abayie et al. 2018). Moreover, the agency theory predicts a negative association 
between CEO duality and financial performance. However, Belkhir (2009) found a positive association between CEO duality and financial performance of commercial banks. Boussaada and Karmani (2015) in their study found no significant relationship between the two variables. The above studies show that CEO duality is an important corporate governance issue that has to be examined in the context of rural banks in Ghana. Board size is one of the most examined corporate governance variables in previous studies (Oteng-Abayie et al. 2018; Musah et al. 2019; Aduseu et al. 2017). Some studies argue in line with agency theory that smaller board sizes are more effective hence are associated with improved financial performance (Adusei, 2011). Other studies argue that larger boards increase the monitoring capacity of the board hence improve financial performance (Adusei et al. 2017). The inconclusive evidence on the subject matter despite its wide use in corporate governance literature was the reason for its inclusion in the study.

Board independent measured by the proportion of non-executive directors have also been widely used in corporate governance studies. Majority of studies agree that higher proportion of non-executive directors is needed to guarantee the independence of the board and improve the monitoring capacity of the board (Andres and Vallelado, 2008; Musah et al. 2019; Adusei et al. 2017). Evidence, however, shows the inconsistent result. For instance, some studies reported a negative association between board independence and financial performance (Romano and Guerrini, 2012). Other studies had no significant association between board independence and financial performance of banks (Love and Rachinsky, 2007; Kyereboah-Coleman 2007; Musah et al. 2019). Finally, the last corporate governance variable was board gender diversity. Mahadeo et al. (2012) reported that a larger proportion of female on the board impact firm performance positively. Solakoglu \& Demir (2016) in their study reported a weak association between gender diversity and firm performance. Oludele et al. $\underline{(2016)}$ reported a positive and significant relationship between gender diversity and firm performance of the listed firms in Nigeria. Julizaema \& Sori (2012) study of Malaysia listed firms reported a positive and significant relationship between gender diversity and firm performance. In the UK, Haslam et al. (2010) studied the relationship between women representation on board and stock-based performance and reported a negative relationship between gender diversity and firm performance. In the United States, Adams \& Ferraira (2009) examined gender diversity and performance of US firms and reported that gender diversified on boards increase monitoring of managers but reported a negative relationship between gender diversity and firm performance. Carter et al. (2010) conducted a similar study in the United States but reported an insignificant association between gender diversity and firm performance. Some studies did not also report any association between gender diversity and firm performance (Babalos et al. 2015; Wachudi \& Mboya, 2016; Musah et al. 2019). Marinova et al. (2010) examined gender diversity and firm performance in the Netherlands and Denmark and reported no significant relationship between gender diversity and firm performance. Based on stakeholder's theory, women representation will enhance the interest of minority groups and increase monitoring of managers. Bart \& McQueen (2013) reported that women representation on board achieved high scores than their male counterparts in complex moral reasoning dimensions which involve making fair decisions when competing interest is at stake. The inclusive result and the little evidence on the subject matter in Ghana justified its inclusion in the model

The study also included bank size as a control variable and a possible determinant of bank performance. Studies on bank performance have always included the size of the bank as one of the key determinants of its financial performance (Musah et al. 2019; Adusei, 2011; Anarfo, 2015). As in most studies in banking and even other studies that use non-banks (Athanasoglou et al., 2008; Adusei, 2011; Anarfo, 2015; Musah et al. 2019), the size of the organization usually has a positive relationship with firm performance. One of the major reasons for this result is the fact that large banks enjoy some economies of scale and even scope which allows them to make higher return margins (Musah et al. 2019). Anarfo (2015) in a study on bank performance noted that large banks can take advantage of large investment opportunities which come with higher risk which smaller banks cannot take. The central bank in Ghana also argues that larger banks improve their liquidity and stability, hence their decision to continuously increase the capital requirement in the sector. 


\section{Results and discussions}

Table 1: Descriptive Statistics of corporate governance variables and Rural Bank Performance

\begin{tabular}{lcrrrr}
\hline Variable & Obs & \multicolumn{1}{c}{ Mean } & \multicolumn{1}{l}{ Std. Dev } & \multicolumn{1}{l}{ Min } & \multicolumn{1}{l}{ Max } \\
\hline ROA & 300 & 0.0463 & 0.0262 & -0.0098 & 0.1398 \\
ROE & 300 & 0.2405 & 0.1162 & -0.0145 & 0.4285 \\
CEO Duality & 300 & 0.0909 & 0.29 & 0 & 1 \\
Board Size & 300 & 7.09 & 0.0525 & 5 & 9 \\
Board Independence & 300 & 0.7541 & 0.2084 & 0.741 & 1 \\
Gender Diversity & 300 & 0.1489 & 0.0862 & 0 & 0.3333 \\
Bank size & 300 & 7.6093 & 0.4571 & 6.667 & 8.3488 \\
\hline
\end{tabular}

The first variable from table 1 is return on assets which is one of the dependent variables used to represent rural bank performance in Ghana. The descriptive analysis from the results above shows that the mean return on assets for rural banks for the study period is $4.63 \%$ with negative $1 \%$ as the minimum performance and $13.98 \%$ as the maximum performance. The results suggest that rural banks in Ghana are able to generate almost $5 \%$ return on their assets in a year. The minimum result of negative $1 \%$ suggests that some banks made a loss over the study period even though from the data collection that was very small. The average return on assets of almost $5 \%$ is above the findings of Musah et al. (2019) study on mainstream banks in Ghana where their study reported an average return on assets of $3.13 \%$. On the other hand, the return on assets of $5 \%$ is lower than the findings of Awunyo-Vitor (2012) where their study reported a mean return on assets for listed banks in Ghana to be $7.9 \%$. The results, however, show that rural banks are largely profitable even though they may not be as profitable as listed commercial banks in Ghana. The second variable from the table is the return on equity which measures the average return on equity holders total interest in the bank over the study period. The results from the table show that the average return to equity holders over the study period is $24 \%$ with negative $1.5 \%$ as the minimum return on equity and $42.85 \%$ as the maximum return on equity. The results show that rural banks can generate over $20 \%$ return on equity holders interest in the banks. The $24 \%$ return on equity for rural banks as reported in the study period is higher than the result of Musah et al. (2019) where they reported an average return on equity for commercial banks to be $15.75 \%$.

The result is however similar to the findings of Awunyo-Vitor (2012) study on listed commercial banks where the average return on equity was about $25 \%$. The result shows that rural banks in Ghana are as profitable than their mainstream banking counterparts even though they are set up to provide banking services to the vulnerable and the less privilege people in the rural parts of the country. The result suggests that banks can still provide financial services to vulnerable people and still be profitable by adopting the right banking strategies. The next variable from the table is one of the main corporate governance variables used in the study. The descriptive analysis shows that on average only $9 \%$ of the rural banks have one person acting as the CEO and the board chairman at the same time. The result suggests that rural banks in Ghana have adopted good corporate governance practices to guide their operations. Good corporate governance practice requires that firms separate the CEO and the board chairman which many of the sampled rural banks have complied. The essence of this separation is to increase the board monitoring of management to ensure that they act in the best interest of shareholders. The next corporate governance variable used in the study is the size of the board of rural banks in Ghana. The board of every organization plays a critical role of charting not just the strategic direction of the organization, but also monitor management behavior and actions to ensure that their decisions and actions maximize the wealth of shareholders. The result from table 1 shows that the average board size of rural banks in Ghana 7 with a minimum board size of 5 and a maximum board size of 9 .

The result is inconsistent with the findings of Musah et al. (2019) where they reported an average board size for commercial banks in Ghana to be 9 and a maximum of 16. The smaller board size for rural banks as compared to commercial banks in Ghana is understandable given that commercial 
banks are far bigger as compared to rural banks and as such will require larger board size to improve the monitoring of management. The next corporate governance included in the study is board independence which was measured as the proportion of non-executive directors on the board. The principles of good corporate governance require that firms that have more non-executive directors as they are more independent and would help improve the board monitoring of management and also improve the governance of the company. On the other hand, another school of thought argue that higher non-executive directors could affect the board ability to monitor management as a result of information asymmetry. The Bank of Ghana guideline for corporate governance issued in 2019 requires financial institutions including rural banks to have a higher proportion of directors to be nonexecutive directors.

The summary of the descriptive analysis of this variable in table 1 shows that the proportion of nonexecutive directors on the board of rural banks in Ghana is $75 \%$. In fact, the study found that some rural banks have all their directors as non-executive directors. The result confirms the earlier assertion that rural banks in Ghana follow good corporate governance principles in terms of their governance structure and also consistent with the Bank of Ghana corporate governance guidelines. The nonexecutive director's proportion of $75 \%$ is a little higher than the findings of Musah et al. (2019) on mainstream banks in Ghana where the study reported a percentage of non-executive directors on the board to be $71 \%$. The last corporate governance variable examined gender diversity of the board of directors. Previous studies on corporate governance argue that diversity on the board helps to improve the board monitoring ability thereby enhancing firm performance and ensuring effective corporate governance. Musah et al. (2019) in their study found evidence of less female representation of the board of commercial banks in Ghana despite the country's clamor for gender inclusivity in both public and private sector organizations.

The result from table 1 shows that about $15 \%$ of board members were female which is consistent with the findings on commercial banks in Ghana. The result of the same variable in Musah et al. (2019) showed female representation on the board of banks to be $16 \%$. The result shows that rural banks are still not convinced that gender diversity will enhance their financial performance as espoused by proponent of this form of diversity as one of the principles of good corporate governance. The last variable which is the only control variable in the study is the size of rural banks which was measured using the natural logarithm of total assets. The study included firm size on the assumption that larger banks can take higher risk and also lend to bigger clients who are usually less risky which will improve financial performance. The average total assets of rural banks from the data collected is GHS62,778,526 with the least total assets of the rural bank over the study period as GHS4,653,500 and the maximum total assets of GHS223, 280,862.

\subsection{Correlation analysis}

Table 2: Correlation Results between ROA and independent variables

\begin{tabular}{lcrrrrr}
\hline & ROA & CEODuality & Bdsize & BDInd & GenderDiversity & BankSize \\
\hline ROA & 1.000 & & & & & \\
CEO Duality & $0.4825^{* *}$ & 1.000 & & & & \\
BDSize & $0.4536^{* *}$ & -0.0276 & 1.000 & & & \\
BDInd & $0.2276^{*}$ & -0.0721 & -0.0175 & 1.000 & & \\
GenderDiversity & -0.1009 & -0.0224 & 0.394 & -0.0149 & 1.000 & \\
bankSize & $0.2147^{*}$ & 0.1209 & 0.2882 & 0.0149 & -0.3399 & 1.000 \\
\hline Note *** means significant at 1\% significance level, ** means significant at 5\% significance level & \\
and $*$ means significant at 10\% significance level. & & & &
\end{tabular}

The result of the correlation analysis in Table 2 shows that all the variables had weak correlation with ROA. The result showed that CEO duality, board size, board independence and rural bank size are all positively correlated with ROA whiles gender diversity is negatively correlated with ROA. 
Table 3 Correlation Results of ROE and Independent variable

\begin{tabular}{lllllll}
\hline & ROE & CEODuality & Bdsize & BDInd & GenderDiversity & BankSize \\
\hline ROE & 1.000 & & & & & \\
CEO Duality & 0.2445 & 1.000 & & & & \\
BDSize & $0.2541^{*}$ & -0.0276 & 1.000 & & & \\
BDInd & $-0.3149 * * *$ & -0.0721 & -0.0175 & 1.000 & & \\
GenderDiversity & -0.1827 & -0.0224 & 0.394 & -0.0149 & 1.000 & 1.000 \\
bankSize & $0.2536^{*}$ & 0.1209 & 0.2882 & 0.0149 & -0.3399 & \\
\hline
\end{tabular}

Note *** means significant at 1\% significance level, ** means significant at 5\% significance level and * means significant at $10 \%$ significance level.

The correlation result in Table 3 showed a positive correlation between CEO duality, board size and bank size are positively correlated with ROE whiles gender diversity and board independence are negatively correlated with ROE.

4.2. Regression analysis

Table 4: Results of Regression Analysis for ROA

\begin{tabular}{lrrr}
\hline Variables & \multicolumn{1}{c}{ Coefficient } & \multicolumn{1}{c}{ Std. Dev. } & \multicolumn{1}{c}{ t-statistics } \\
\hline CEO Duality & 0.0034 & 0.00364 & 0.9264 \\
Board Size & 0.0007 & 0.00080 & 0.8270 \\
Board Independence & $0.0119 * * *$ & 0.00346 & 3.4330 \\
Gender Diversity & -0.0044 & 0.00437 & -1.0149 \\
Bank size & $0.1260^{* * *}$ & 0.02856 & 4.4101 \\
CONS & $0.2691 * * *$ & -0.06567 & -4.0977 \\
F-Statistics & 4.3500 & & \\
Prob>F & 0.0010 & & \\
Adjusted R-square & 0.5165 & & \\
\hline
\end{tabular}

Note *** means significant at 1\% significance level, ** means significant at 5\% significance level and * means significant at $10 \%$ significance level.

Table 5: Results of Regression Analysis for ROE

\begin{tabular}{lrrr}
\hline Variables & \multicolumn{1}{c}{ Coefficient } & \multicolumn{1}{c}{ Std. Dev. } & \multicolumn{1}{c}{ t-statistics } \\
\hline CEO Duality & 0.0921 & 0.0547 & 1.68 \\
Board Size & $0.04415^{* *}$ & 0.0193 & 2.3 \\
Board Independence & $0.00164^{* *}$ & 0.0075 & 2.17 \\
Gender Diversity & $-4.7082^{*}$ & 0.2442 & -1.93 \\
Bank size & 0.0062 & 0.0446 & 0.14 \\
CONS & 0.04455 & 0.30846 & 0.15 \\
F-Statistics & 3.38 & & \\
Prob>F & 0.01 & & \\
Adjusted R-Square & 0.446 & & \\
\hline Note & & \\
\hline
\end{tabular}

Note *** means significant at $1 \%$ significance level, ** means significant at $5 \%$ significance level and * means significant at $10 \%$ significance level.

The variable in Table 4 and 5 is CEO duality which examined its influence on rural bank financial performance. The correlation statistics as well as the resgression coefficient for both dependent varibles revealed a positive coefficient between CEO duality and rural bank performance in Ghana. However, both positive coefficients were statistically insignificant which means that CEO duality is 
not a significant determinant of rural bank performance in Ghana. The result could be interpreted to mean that even though rural banks that have one person as both the CEO and board chairperson may have improved financial performance, the improvement is not significant. The result is contrary to the expectation of the third hypothesis of the study (H3) which proposed a negative association between CEO duality and financial performance of rural banks. The result is also at variance with the findings of Belkhir (2009b) who reported a positive coefficient between CEO duality and firm performance. It is also contrary to the result of Mishra and Nielsen (2000) who reported a negative association between the two variables. On the other hand, the result is consistent with the results of Boussaada and Karmani (2015) where thy found evidence of no significant association between CEO duality and bank performance in the Middle East and North African regions.

The second board size focused on the association between the number of directors on the board of rural bank and its financial performance. The correlation analysis for return on assets and return on equity showed a positive correlation between board size and financial performance of rural banks in Ghana. The result shows that the relationship between board size and return on assets was statistically significant but that of board size and return on equity was positive but statistically insignificant. The regression analysis showed that there was a positive relationship between board size and return on assets and the relationship was also statistically significant. The study found a positive association between board size and return on equity even though the relationship was statistically insignificant. The result suggests that rural banks with larger boards size have higher performance in terms of profitability as compared to those with smaller board size. Jensen (1983) argued that too much larger board does not enhance board effectiveness which was corroborated by Florackis and Ozkan (2004) who argue that board size above eight might not be effective. Given that the average board size or rural banks is 7, it can be argued that their size is within the accepted range which explains why there is a positive relationship between the size of the board and rural bank financial performance. The result is in agreement with the first hypothesis of the study which argued that there is a positive coefficient between board size and financial performance of rural banks in Ghana. The result is in agreement with the findings of Adams and Mehran (2005) and (2008) where they found evidence of a positive and significant association between board size and financial performance of commercial banks in the United States. The result is also consistent with the findings of Andres and Vallelado (2008) who reported a positive association between board size and large commercial banks in some selected European countries. The result is also consistent with the findings of Musah et al. (2019) based on their study on a sample of mainstream banks in Ghana. The result is however contrary to the findings of some studies which reported a negative association between the size of a board and the financial performance of the firm (Staikouras et al., 2007; Labelle and Trabelsi, 2010).

The third objective of the study examined the influence of board gender diversity on the financial performance of rural banks in Ghana. Both correlation analysis and regression analysis revealed a negative association between board gender diversity and financial performance of rural banks in Ghana. The correlation coefficient in both cases however weak suggesting that the correlation between financial performance of rural banks and their board gender diversity is not strong. The regression analysis showed a negative association between board gender diversity and both return on assets and return on equity consistent with the findings of the correlation analysis. The association between board gender diversity and return on equity showed weak statistical significance at $10 \%$ significance level while not significant association was found between board gender diversity and return on assets. The result seems to suggest that board gender diversity is not a significant determinant of the financial performance of rural banks in Ghana. The result is contrary to the expectation of the fourth hypothesis ( $\mathrm{H} 4)$ of the study that predicted a positive coefficient between board gender diversity and rural banks financial performance in Ghana. The result is in agreement with that of De Cabo et al (2012) where they reported no significant association between female members on the board and financial performance of banks in Europe.teh result agrees in part with Musah et al. (2019) where they reported a negative but statistically insignificant association between female representation on the board and ROA and ROE of commercial banks in Ghana. Furthermore, the result is also at variance with the findings of Romano et al. (2012) where they reported a positive coefficient between female board representation and financial performance of banks. The result calls 
for greater introspection on gender diversity and how it can be deployed to help improve financial performance of rural banks in Ghana.

The last independent variable looked at the relationship between independent board members and rural bank financial performance in Ghana. Both correlation analysis in table 2 and 3 showed a positive correlation between the two variables even though weak. The regression analysis revealed that the proportion of non-executive directors on the board of rural banks in Ghana is positively associated with return on assets and return on equity of rural banks in Ghana. The results were also statistically significant suggesting that board independence is a significant determinant of financial performance of rural banks in Ghana. The result is in agreement with the second hypothesis $(\mathrm{H} 2)$ which predicts a positive relationship between board independence and financial performance of rural banks in Ghana. The results suggest that independent directors can use their independence and expertise to work to improve the performance of rural banks in Ghana. The result is also in agreement with several studies that found evidence of positive relationship between board independence and financial performance of firms (Staikouras et al. 2007; Busta, 2007; Musah et al. 2019). Some few studies found evidence contrary to the findings of this study (Kyereboah-Coleman, 2007; Love and Rachinsky, 2007). The result is an endorsement of the bank of Ghana directive on corporate governance for financial institutions in Ghana which require them to have more non-executive directors on their board.

\section{Conclusion}

The study examined the influence of corporate governance structures such as CEO duality, the board size, proportion of non-executive directors on the board and board gender diversity on financial performance of rural banks in Ghana using a sample of 30 rural banks over a 10-year period from 2010 to 2019. Descriptive statistics, correlation analysis and panel regression analysis were adopted to analyze the data to achieve the objective of the study. The result shows that there was a positive but statistically insignificant association between CEO duality and ROA and ROE. The result further showed a positive but statistically insignificant association between board size and ROA and ROE. In addition to the above, the regression analysis as well as correlation analysis showed a negative association between gender diversity on the board and financial performance of rural banks. The association between gender diversity on the board and ROE was significant at $10 \%$ whiles that of ROA was statistically insignificant. The study also showed a positive and statistically significant association between the proportion of non-executive directors on the board of directors of rural banks in Ghana and ROA and ROE suggesting that board independence is significant determinant of financial performance of rural banks in Ghana.

Based on the findings discussed above, the following recommendations can be drawn.

First, Rural banks should endeavor to separate CEO and Board Chairperson in compliance with good corporate governance principles and also the Bank of Ghana guidelines on Good corporate governance for financial institutions issued in 2019. The basis of this argument is the fact that, the study did not find evidence of a significant positive relationship between board CEO duality and financial performance of rural banks in Ghana. The study also recommends that rural banks should continue to have a significant proportion of their board members as non-executive directors as that have a significant impact on financial performance. The study result showed that gender diversity on the board reduce financial performance of rural banks. This means that rural bank stakeholders and regulators cannot rely on female representation to improve their financial performance.

\section{References}

Abad, D., Lucas-Pérez, M. E., Minguez-Vera, A., \& Yagüe, J. (2017). Does gender diversity on corporate boards reduce information asymmetry in equity markets?. BRQ Business Research Quarterly, 20(3), 192-205.

Aboagye, A. Q., \& Otieku, J. (2010). Are Ghanaian MFIs' performance associated with corporate governance?. Corporate Governance: The International Journal of Business in Society, 10(3), 307-320. 
Abor, J., \& Adjasi, C. K. (2007). Corporate governance and the small and medium enterprises sector: theory and implications. Corporate Governance: The International Journal of Business in Society, 7(2), 111-122.

Abor, J., \& Biekpe, N. (2007). Corporate governance, ownership structure and performance of SMEs in Ghana: implications for financing opportunities. Corporate Governance: The International Journal of Business in Society, 7(3), 288-300.

Adams, R. B., \& Ferreira, D. (2007). A theory of friendly boards. The journal of finance, 62(1), 217-250.

Adams, R. B., \& Mehran, H. (2012). Bank board structure and performance: Evidence for large bank holding companies. Journal of Financial Intermediation, 21(2), 243-267.

Adnan, M. A., Htay, S. N. N., Rashid, H. M. A., \& Meera, A. K. M. (2011). A panel data analysis on the relationship between corporate governance and bank efficiency. Journal of Accounting, 1(1). 1-15.

Adu-Amoah, A., Tsamenyi, M., \& Onumah, J. M. (2008). The influence of social and political relations on corporate governance systems: The case of rural banks in Ghana. Research in Accounting in Emerging Economies, 8(1), 311-334.

Adusei, M. (2011). Board structure and bank performance in Ghana. Journal of Money, Investment and Banking, 19(1), 72-84.

Adusei, M., Akomea, S. Y., \& Poku, K. (2017). Board and management gender diversity and financial performance of microfinance institutions. Cogent Business \& Management, 4(1), 1360030.

Amoateng, A. K., Osei, K. T., Ofori, A., \& Gyabaa, E. N. (2017). Empirical study on the impact of corporate governance practices on performance: evidence from SMEs in an emerging economy. European Journal of Accounting Auditing and Finance Research, 5(8), 50-61.

Anarfo, E. B. (2015). Capital structure and bank performance-evidence from Sub-Sahara Africa. European Journal of Accounting, Auditing and Finance Research, 3(3), 1-20.

Anbar, A., \& Alper, D. (2011). Bank specific and macroeconomic determinants of commercial bank profitability: Empirical evidence from Turkey. Business and Economics Research Journal, 2(2), 139-152.

Antwi, S., \& Binfor, F. (2013). The effect of corporate governance on strategic change in financial institutions: evidence from Ghana. International Journal of Academic Research in Business and Social Sciences, 3(3), 159.

Appiah, K. O., Chizema, A., \& Arthur, J. (2015). Predicting corporate failure: a systematic literature review of methodological issues. International Journal of Law and Management, 57(5), 461-485.

Athanasoglou, P. P., Brissimis, S. N., \& Delis, M. D. (2008). Bank-specific, industry-specific and macroeconomic determinants of bank profitability. Journal of International Financial Markets, Institutions and Money, 18(2), 121-136.

Atta Mills, E., \& Amowine, N. (2013). The rural bank profitability nexus: evidence from Ghana. International Journal of Application or Innovation in Engineering and Management, 2(4).

Awunyo-Vitor, D., \& Badu, J. (2012). Capital structure and performance of listed banks in Ghana. Global Journal of Human-Social Science Research, 12(5).

Babalos, V., Caporale, G. M., \& Philippas, N. (2015). Gender, style diversity, and their effect on fund performance. Research in International Business and Finance, 35, 57-74.

Bart, C., \& McQueen, G. (2013). Why women make better directors. International Journal of Business Governance and Ethics, 8(1), 93-99.

Belkhir, M. (2009). Board of directors' size and performance in the banking industry. International Journal of Managerial Finance, 5(2), 201-221.

Belkhir, M. (2009b). Board structure, ownership structure and firm performance: evidence from banking. Applied financial economics, 19(19), 1581-1593.

Bokpin, G. A., \& Arko, A. C. (2009). Ownership structure, corporate governance and capital structure decisions of firms: Empirical evidence from Ghana. Studies in Economics and Finance, 26(4), 246-256. 
Bokpin, G. A., \& Isshaq, Z. (2009). Corporate governance, disclosure and foreign share ownership on the Ghana Stock Exchange. Managerial Auditing Journal, 24(7), 688-703.

Boussaada, R., \& Karmani, M. (2015). Ownership concentration and bank performance: evidence from MENA banks. International Journal of Business and Management, 10(3), 189-202.

Busta, I. (2007, May). Board effectiveness and the impact of the legal family in the European banking industry. In FMA European Conference.

Carter, D. A., D'Souza, F., Simkins, B. J., \& Simpson, W. G. (2010). The gender and ethnic diversity of US boards and board committees and firm financial performance. Corporate Governance: An International Review, 18(5), 396-414.

Claessens, S., \& Fan, J. P. (2003). Corporate governance in Asia: a survey. Available at SSRN 386481 .

De Andres, P., \& Vallelado, E. (2008). Corporate governance in banking: The role of the board of directors. Journal of banking \& finance, 32(12), 2570-2580.

De Cabo, R. M., Gimeno, R., \& Nieto, M. J. (2012). Gender diversity on European banks' boards of directors. Journal of Business Ethics, 109(2), 145-162.

Fama, E. F., \& Jensen, M. C. (1983). Separation of ownership and control. The journal of law and Economics, 26(2), 301-325.

Florackis, C., \& Ozkan, A. (2004). Agency costs and corporate governance mechanisms: Evidence for UK firms, university of york. UK. Working Paper Series.

Gersick, C. J. (1988). Time and transition in work teams: toward a new model of group development. Academy of Management journal, 31(1), 9-41.

Golden, B. R., \& Zajac, E. J. (2001). When will boards influence strategy? Inclination $\times$ power= strategic change. Strategic Management Journal, 22(12), 1087-1111.

Haslam, S. A., Ryan, M. K., Kulich, C., Trojanowski, G., \& Atkins, C. (2010). Investing with prejudice: The relationship between women's presence on company boards and objective and subjective measures of company performance. British Journal of Management, 21(2), 484497.

Isshaq, Z., Bokpin, G. A., \& Mensah Onumah, J. (2009). Corporate governance, ownership structure, cash holdings, and firm value on the Ghana Stock Exchange. The Journal of Risk Finance, 10(5), 488-499.

Julizaerma, M. K., and Sori, Z. M. (2012). Gender diversity in the boardroom and firm performance of Malaysian public listed companies. Procedia - Social and Behavioral Sciences, 65, 1077 - 1085

Kyereboah-Coleman, A. (2007). Corporate governance and shareholder value maximization: an African perspective. African Development Review, 19(2), 350-367.

Kyereboah-Coleman, A., \& Biekpe, N. (2006). The relationship between board size, board composition, CEO duality and firm performance: Experience from Ghana. Corporate Ownership and Control, 4(2), 114-122.

Labelle, R., \& Trabelsi, S. (2010). The economic consequences of disclosure regulation: evidence from online disclosure of corporate governance practices in US and Canadian markets. In CAAA Annual Conference.

Love, I., \& Rachinsky, A. (2007). Corporate governance, ownership and bank performance in emerging markets: evidence from Russia and Ukraine. World Bank, Working Paper.

Mahadeo, J. D., Soobaroyen, T., \& Hanuman, V. O. (2012). Board composition and financial performance: Uncovering the effects of diversity in an emerging economy. Journal of business ethics, 105(3), 375-388.

Marinova, J. H., Plantenga, J., \& Remery, C. L. H. S. (2010). Gender diversity and firm performance: Evidence from Dutch and Danish boardrooms. Discussion Paper Series/Tjalling C. Koopmans Research Institute, 10(03).

Mishra, S., \& Mohanty, P. (2000). Does good governance lead to better financial performance?. International Journal of Corporate Governance, 9(4), 462-480.

Monks, R. A. G., \& Minow, N. (1995). Corporate governance on equity ownership and corporate value. Journal of financial Economics, 20(3), 293-315.

Musah, A. (2017). The impact of capital structure on profitability of commercial banks in Ghana. Asian Journal of Economic Modelling, 6(1), 21-36. 
Musah, A., Adjei, E., Akomeah, E., \& Ahmed, I. A. (2019). Corporate governance, gender diversity and bank performance: evidence from Ghana. Indonesian Journal of Corporate Governance and Social Responsibility, 1(1).

OECD, O. (2004). The OECD principles of corporate governance. Contaduría y Administración, (216).

Oludele, O., Margret, O., \& Tobiah, O. (2016). The Relationship between Board Independence and Financial performance of listed manufacturing companies in Nigeria. European Journal of Business, Economics and Accountancy, 4(9), 45-56.

Oteng-Abayie, E. F. (2017). Technical efficiency and total factor productivity of rural banks in Ghana. Cogent Economics \& Finance, 5(1), 1366088.

Oteng-Abayie, E. F., Affram, A., \& Mensah, H. K. (2018). Corporate governance and efficiency of rural and community banks (RCBs) in Ghana. Econometric Research in Finance, 3(2), 93-118.

Owusu-Antwi, G., Mensah, L., Crabbe, M., \& Antwi, J. (2015). Determinants of bank performance in Ghana, the Economic Value Added (EVA) Approach. International Journal of Economics and Finance, 7(1), 204-215.

Pi, L., \& Timme, S. G. (1993). Corporate control and bank efficiency. Journal of Banking \& Finance, 17(2-3), 515-530.

Romano, G., \& Guerrini, A. (2012). Corporate governance and accounting enforcement actions in Italy. Managerial Auditing Journal. 27(7), 622-638.

Romano, G., Ferretti, P., \& Rigolini, A. (2012, September). Corporate governance and performance in Italian banking groups. In Paper to be presented at the International conference (pp. 1-35).

Sarkar, J., \& Sarkar, S. (2018). Bank ownership, board characteristics and performance: Evidence from commercial banks in India. International Journal of Financial Studies, 6(1), 17.

Selvam, M., Raja, J., \& Kumar, A. S. (2006, July). Corporate governance and performanceindian banking system. In International Conference on Business and Information, Hong Kong Baptist University.

Solakoglu, M. N., \& Demir, N. (2016). The role of firm characteristics on the relationship between gender diversity and firm performance. Management Decision, 54(6), 14071419.

Staikouras, P. K., Staikouras, C. K., \& Agoraki, M. E. K. (2007). The effect of board size and composition on European bank performance. European Journal of Law and Economics, 23(1), 1-27.

Wachudi, E. J., \& Mboya, J. (2012). Effect of board gender diversity on the performance of commercial banks in Kenya. European Scientific Journal, ESJ, 8(7). 